\begin{tabular}{ll}
\hline \hline MINING AND METALLURGY INSTITUTE BOR & ISSN: 2334-8836 (Štampano izdanje) \\
UDK: 622 & ISSN: 2406-1395 (Online) \\
\hline \hline
\end{tabular}

\title{
THE EFFECT OF IMPURITIES ON HIGH-TEMPERATURE RESISTANCE OF PLATINUM AND ITS ALLOYS ${ }^{* *}$
}

\begin{abstract}
This paper presents the testing results of impact both the individual and total content of impurities in platinum and its alloys of different purity. Relative probability is presented of distribution of $\mathrm{Al}, \mathrm{Si}, \mathrm{Fe}$, $\mathrm{Mg}, \mathrm{Ni}, \mathrm{Pb}, \mathrm{Cu}, \mathrm{Ag}$, as well as their maximum content in the alloys of PtRh7, PtRh10, PtRh5Pd15 and PtRh5Pd15Rul.5 composition. Also, the results of impact the purity degree of platinum to its high temperature resistance are given after applied thermo-mechanical processing regime. The conclusion is that, if content of impurities is higher in platinum metals and alloys, greater is the probability of their negative impact on technological and exploitation properties.
\end{abstract}

Keywords: impurities, platinum, platinum alloys, high temperature resistance

\section{INTRODUCTION}

The presence of chemical elements impurities in platinum metals and alloys is related to the composition of starting mineral raw materials as well as the technological processes for their obtaining, processing and exploitation in the industrial conditions [1-3].

The presence of impurities in platinum metals and alloys has a major impact on their physical and mechanical properties. Due to this reason, the purity of platinum metals and alloys is one of their key characteristics [4-6]. The conditional definition of platinum metals of technical (99.50\% wt.), chemical (99.90\% wt.), physical $(99.99 \%$ wt.) and spectral (99.999\% wt.) purity is often used to evaluate the cumulative content of impurities. In accordance with the present standard, platinum metals are divided into three groups: type A-0, A-1 and
A-2 with the corresponding following purities: $99.98,99.95$ and $99.90 \%$ [7-11].

Purity of platinum is determined by calculation from the difference $100 \%$ of metal mass and the sum of percent of 10-15 control impurities. In addition, the total number of control impurities, as a rule, also includes the platinum group of metals and gold. Impurities such as Rh, Ru Pd, Ir and Au lead to an improvement of mechanical characteristics of platinum, or to increase of its high temperature resistance [13].

For example, contaminated platinum with content of $0.055 \%$ of other platinum metals and gold, can be considerably better batch material in comparison to pure platinum type A-0 with $0.01 \%$ impurities such as $\mathrm{Si}, \mathrm{Al}, \mathrm{Pb}$, and others, but at the same time represent a very unfavorable batch material for making the high-temperature alloys.

\footnotetext{
* Mining and Metallurgy Institute Bor, Zeleni bulevar 33, Bor, Serbia

** This work is the result of the project TR 34029, "Development of Production Technology of Pd catalyst-catcher to Reduce the Losses of Platinum in High Temperature Processes of Catalysis", funded by the Ministry of Education, Science and Technological Development of the Republic of Serbia
} 


\section{EXPERIMENTAL TECHNIQUE}

However, an important classification of platinum metals do not take into account the possible existence of 50-70 usually not control impurities, whose cumulative content may amount to $10^{-2}-10^{-3} \%$ wt [14].
Platinum, rhodium and palladium for making the alloys were obtained as a by-product within the production of electrolytic copper in RTB, Serbia. The required purity is achieved by the additional refining. Composition of analyzed alloys is listed in Table 1.

Table 1 Content of alloying elements in the analyzed samples (mass \%)

\begin{tabular}{|l|c|c|c|}
\hline Alloy & Rh (mass\%) & Pd (mass\%) & Ru (mass\%) \\
\hline PtRh7 & 7 & - & - \\
\hline PtRh10 & 10 & - & - \\
\hline PtRh5Pd15 & 5 & 15 & - \\
\hline PtRh5Pd15Ru1.5 & 5 & 15 & 1.5 \\
\hline
\end{tabular}

Melting of samples was carried out in a medium-frequency induction oven. Annealing of samples was carried out in an electric resistance oven, type LP08.

A universal device for tension testing of materials at high temperature, manufacturer Karl Frank, type 81221, was used to test the mechanical characteristics of samples.

Chemical analysis of material for samples was carried out on atomic absorption spectrophotometer.

\section{RESULTS AND DISCUSSION}

Products based on platinum and its alloys are widely used in many branches of modern industry, primarily in chemical industry.

For durability and efficiency of listed products in the exploitation conditions, the purity of starting materials is very important.

For this purpose, the control of impurities in platinum and platinum alloys in all stages of technological and exploitation process, occupies a very important place.

Results of testing the content of certain impurities in the starting material (Pt Type A-1 (99.95\% wt.) from which the alloy of composition PtRh20Pd10Ir0.1Au0.1 was synthesized, are given in Table 2.

Table 2 Individual content of impurities in platinum $99.95 \%$

\begin{tabular}{|c|c|c|c|c|c|c|c|c|c|}
\hline Element & Be & B & F & Na & He & Ge & As & Se & Pr \\
\hline c $\times 10^{-5,} \% 0.03-0.09$ & $0.01-0.60$ & $7.0-80$ & $0.2-40$ & $1.3-8.3$ & $2.8-7.7$ & $1.5-22$ & $0.06-3.9$ & $1.5-2.7$ \\
\hline
\end{tabular}

\begin{tabular}{|c|c|c|c|c|c|c|c|c|c|}
\hline Element & Ti & $\mathbf{V}$ & $\mathbf{C r}$ & $\mathbf{N d}$ & $\mathbf{S m}$ & $\mathbf{E u}$ & $\mathbf{M g}$ & $\mathbf{A l}$ & $\mathbf{S i}$ \\
\hline $\mathrm{c} \times 10^{-5}, \%$ & $1.8-230$ & $0.08-3.0$ & $2.5-13$ & $1.5-2.8$ & $1.5-2.9$ & $1.6-3.0$ & $3.0-90$ & $0.8-480$ & $1.7-82$ \\
\hline
\end{tabular}

\begin{tabular}{|c|c|c|c|c|c|c|c|c|c|}
\hline Element & $\mathbf{P}$ & $\mathbf{S}$ & $\mathbf{C l}$ & $\mathbf{K}$ & $\mathbf{C a}$ & $\mathbf{R b}$ & $\mathbf{S r}$ & $\mathbf{Y}$ & $\mathbf{Z r}$ \\
\hline $\mathrm{c} \times 10^{-5}, \%$ & $0.05-12$ & $0.8-2.8$ & $0.07-3100$ & $0.1-2.2$ & $0.5-31$ & $0.1-5.1$ & $0.1-0.3$ & $0.2-0.5$ & $0.4-3.3$ \\
\hline
\end{tabular}

\begin{tabular}{|c|c|c|c|c|c|c|c|c|c|}
\hline Element & Nb & Mo & Ag & Dy & Ho & Er & Tm & Yb & Lu \\
\hline $\mathrm{c} \times 10^{-5}, \%$ & $0.1-0.6$ & $0.3-9.3$ & $2.0-62$ & $1.7-3.2$ & $1.7-3.2$ & $1.7-3.2$ & $1.7-3.3$ & $1.8-3.4$ & $1.8-3.4$ \\
\hline
\end{tabular}

\begin{tabular}{|c|c|c|c|c|c|c|c|c|c|}
\hline Element & Sc & Mn & Fe & Co & Ni & Cu & Zn & Br & Cd \\
\hline c $\times 10^{-5}, \%$ & $0.04-0.46$ & $0.5-1.1$ & $0.05-370$ & $10 .-23$ & $3.9-520$ & $3.6-85$ & $1.7-310$ & $0.9-4.1$ & $1.6-3.1$ \\
\hline
\end{tabular}




\begin{tabular}{|c|c|c|c|c|c|c|c|c|c|}
\hline Element & $\mathbf{T b}$ & $\mathbf{O}_{\mathbf{2}}$ & $\mathbf{C}$ & $\mathbf{C u}$ & $\mathbf{I n}$ & $\mathbf{S n}$ & $\mathbf{S b}$ & $\mathbf{T e}$ & $\mathbf{I}$ \\
\hline $\mathrm{c} \times 10^{-5}, \%$ & $1.6-3.1$ & 310 & 15 & $0.9-6.5$ & $0.3-3.4$ & $2.3-11$ & $1.0-4.2$ & $6.2-36$ & $0.3-2.4$ \\
\hline
\end{tabular}

\begin{tabular}{|c|c|c|c|c|c|c|c|c|c|}
\hline Element & Cs & Ba & La & Ce & Hf & Ta & W & Re & Hg \\
\hline $\mathrm{c} \times 10^{-5}, \%$ & $4.1-18$ & $0.4-4.0$ & $1.4-2.7$ & $1.4-2.7$ & $1.2-3.5$ & $3.4-22$ & $2.8-8.9$ & $1.9-11$ & $1.6-9.0$ \\
\hline
\end{tabular}

\begin{tabular}{|c|c|c|c|c|c|}
\hline Element & Tl & Pb & Bi & Th & U \\
\hline $\mathrm{c} \times 10^{-5}, \%$ & $0.3-34$ & $5.9-110$ & $0.7-61$ & $0.8-1.6$ & $0.9-1.8$ \\
\hline
\end{tabular}

It is obvious that the individual contents of nonvolatile impurities in platinum type A-1 $(99.95 \%)$ and alloys based on them is in the range of $\mathrm{c} \times 10^{-7}$ to $\mathrm{c} \times 10^{-3} \%$. Total content of all 68 impurities of base metals and Ag does not exceed $0.02 \%$.
In platinum alloys, intended for industrial conditions, total content of 10-12 control impurities, in many cases, can be very high, up to $0.1 \%$, although it is often no more than $0.02-0.05 \%$ (Table 3 and Figure 1).

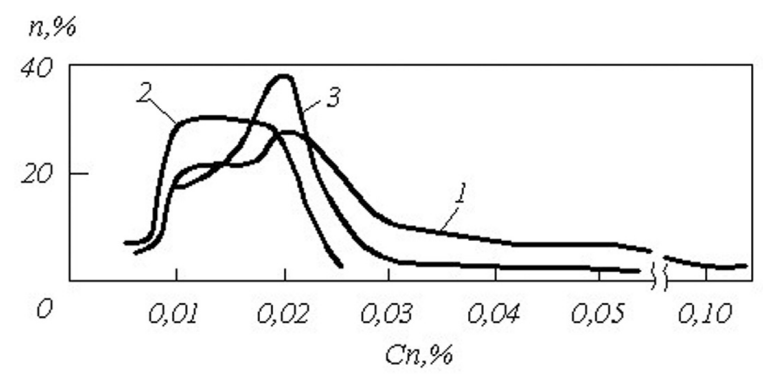

Figure 1 Relative probability of distribution the control impurities ( $n)$, in the function of concentration, $c_{n}$, in the alloys PtRh10 (1), PtRh7 (2) and PtRh5Pd15 (3) [12]

Table 3 Maximum content of control impurities of base metals and Ag in platinum alloys in wt\%

\begin{tabular}{|c|c|c|c|c|}
\hline Impurities & PtRh7 & PtRh10 & PtRh5Pd15 & PtRh10Pd25Ru1.5 \\
\hline $\mathbf{A g}$ & 0.003 & 0.012 & 0.003 & 0.003 \\
\hline $\mathbf{F e}$ & 0.010 & 0.030 & 0.015 & 0.010 \\
\hline $\mathbf{M g}$ & 0.020 & 0.025 & 0.020 & 0.010 \\
\hline $\mathbf{C u}$ & 0.001 & 0.001 & 0.014 & 0.003 \\
\hline $\mathbf{N i}$ & - & - & 0.003 & - \\
\hline $\mathbf{P b}$ & - & - & 0.003 & - \\
\hline $\mathbf{A l}$ & 0.005 & 0.006 & 0.002 & 0.003 \\
\hline $\mathbf{S i}$ & - & 0.007 & 0.003 & 0.002 \\
\hline $\mathbf{S}$ & - & 0.010 & - & - \\
\hline$\Sigma$ & 0.04 & 0.10 & 0.07 & 0.03 \\
\hline
\end{tabular}

Concentration of some impurities is some impurities increases to 0.004generally lower than 0.001 to $0.002 \%$, and the cases may be when the content of $0.006 \%$ and further to $0.01-0.03 \%$, as shown in Figure 2. 

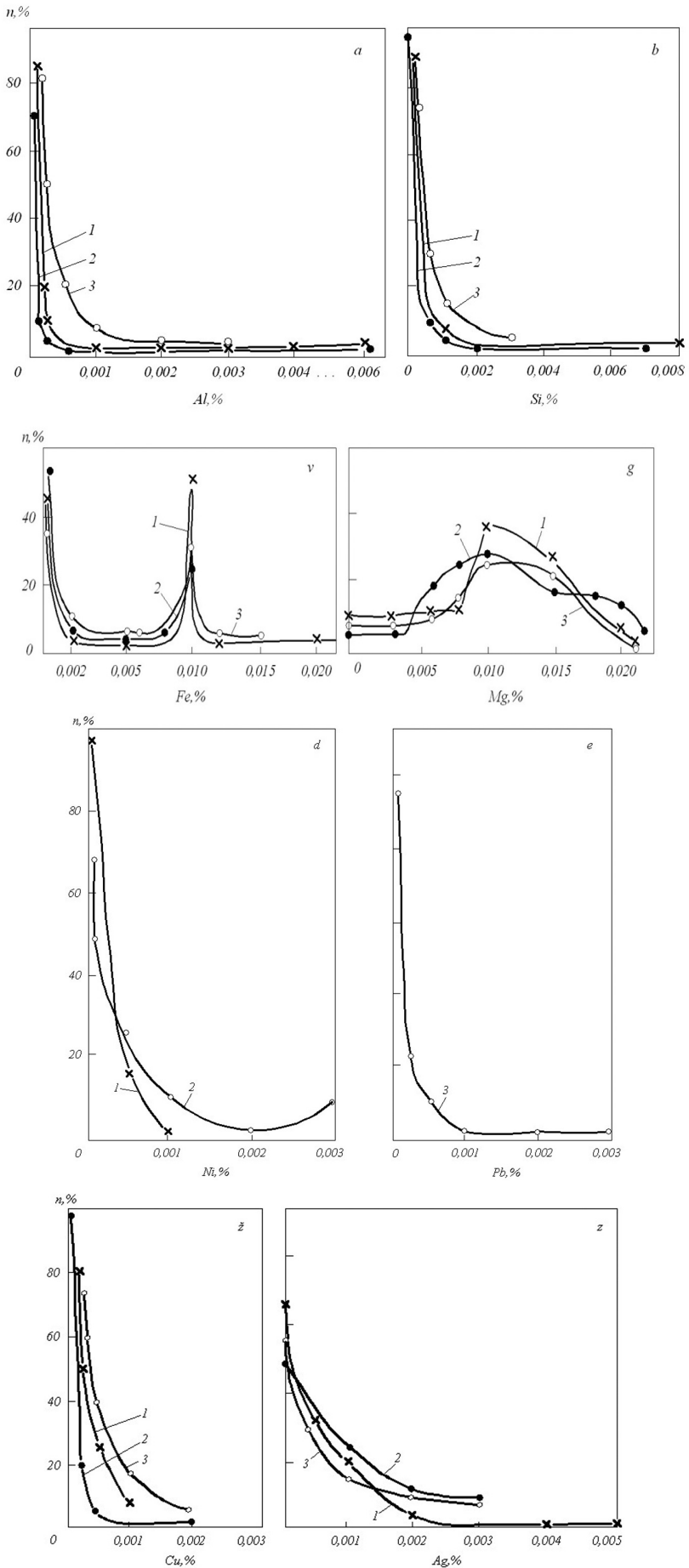

Figure 2 Relative probability of distribution the aluminum (a), silica (b), iron (c), magnesium (d), nickel (e), lead (f), copper (g) and silver ( $h$ ) in the alloys PtRh10 (1), PtRh7 (2) and PtRh5Pd15Rul.5 
Particular attention is turned by distribution of $\mathrm{Mg}$ and $\mathrm{Fe}$ (at content higher than $0.005 \%$ ), which is characterized by the whole Gaussian curves, while distribution of others analyzed impurities presents only the right side of distribution curve by Gauss. The assumption is that the top and left side of distribution curve by Gauss, are in such low concentrations of analyzed impurities, which are impossible to identify using the method of spectral analysis.

Maximum on distribution curves of total content, Figure 1, as well as distribution of Fe and $\mathrm{Mg}$, Figure 2, correspond to the concentration of $0.01-0.02 \%$. It is obvious that $\mathrm{Fe}$ and $\mathrm{Mg}$ are the main pollutants of platinum alloys. The curve of $\mathrm{Fe}$ of distribution is characterized by two peaks, at concentration of 0.001 and $0.01 \%$. The left peak (concentration of $0.001 \%$ ) corresponds to the content of iron in the initial batch, while the right peak (concentration $0.01 \%$ ) most likely corresponds to the dirty scratched alloy in the processing and exploitation process.
Contamination of platinum alloys with magnesium in the amount of 0.005 $0.015 \%$ is associated with the melting of platinum alloys in ceramic pots of $\mathrm{MgO}$ composition as magnesium content in the starting batch does not exceed the concentration of 0.001 to 0003 .

According to the English standard, high purity platinum content has permitted following impurities in \%: $1 \times 10^{-5} \mathrm{Cu} ; 1 \times 10^{-5} \mathrm{Ag}$; $<1 \times 10^{-4} \mathrm{~Pb} ; 7 \times 10^{-5} \mathrm{Fe} ;<1 \times 10^{-4} \mathrm{Ni} ;<1 \times 10^{-4}$ $\mathrm{Mg} ;<1 \times 10^{-5} \mathrm{Zr} ; 4 \times 10^{-4} \mathrm{O}_{2} ; 2 \times 10^{-5} \mathrm{Pd} ; 2 \times 10^{-5}$ $\mathrm{Rh} ;<1 \times 10^{-4} \mathrm{Au}[12]$.

Based on the allowable content of impurities, according to this standard, high purity platinum can be reached only in its obtaining by chemical methods, while the zonal refining in a stream of oxygen or removing of impurities at high temperatures in a stream of oxygen or vacuum, can significantly reduce the quantities of these impurities.

Table 4 presents the results obtained by AAS technique for platinum purity of $99.999 \%$.

Table 4 Content of impurities in platinum purity of $99.999 \%$

\begin{tabular}{|c|c|c|c|c|c|c|c|c|c|}
\hline Element & $\mathbf{P b}$ & $\mathbf{W}$ & $\mathbf{T a}$ & $\mathbf{A g}$ & $\mathbf{C u}$ & $\mathbf{N i}$ & $\mathbf{F e}$ & $\mathbf{C r}$ & $\mathbf{T i}$ \\
\hline $\mathrm{c} \times 10^{-4}, \%$ & $1 \times 10^{-5}$ & $4 \times 10^{-6}$ & $3 \times 10^{-5}$ & $6 \times 10^{-6}$ & $5 \times 10^{-6}$ & $1.5 \times 10^{-4}$ & $2 \times 10^{-3}$ & $1.2 \times 10^{-4}$ & $1.4 \times 10^{-4}$ \\
\hline
\end{tabular}

\begin{tabular}{|c|c|c|c|c|c|c|c|c|c|}
\hline Element & $\mathbf{C a}$ & $\mathbf{S}$ & $\mathbf{P}$ & $\mathbf{S i}$ & $\mathbf{A l}$ & $\mathbf{M g}$ & $\mathbf{N a}$ & $\mathbf{O}_{\mathbf{2}}$ & $\mathbf{N}$ \\
\hline $\mathrm{c} \times 10^{-5}, \%$ & $3 \times 10^{-4}$ & $3 \times 10^{-4}$ & $1 \times 10^{-4}$ & $7 \times 10^{-4}$ & $1 \times 10^{-3}$ & $3 \times 10^{-4}$ & $1 \times 10^{-4}$ & $3 \times 10^{-3}$ & $1 \times 10^{-3}$ \\
\hline
\end{tabular}

\begin{tabular}{|c|c|c|c|c|}
\hline Element & B & Au & Pd & Rh \\
\hline $\mathrm{c} \times 10^{-5}, \%$ & $4 \times 10^{-3}$ & $3 \times 10^{-5}$ & $2.7 \times 10^{-3}$ & $3 \times 10^{-5}$ \\
\hline
\end{tabular}

Tendency for obtaining the platinum metals and alloys of high purity is directed towards the goal of achieving the certain exploitation characteristics, as well as the necessity of preventing crack for mations in hot forging and metal processing.

Table 5 presents the results of impact the degree of purity on platinum hardness after deformation and annealing at $600^{\circ} \mathrm{C}$ for $0.5 \mathrm{~h}$.

Table 5 Hardness of different purity platinum (sheet metal)

\begin{tabular}{|c|c|c|c|c|}
\hline Platinum purity & $\boldsymbol{\varepsilon}, \boldsymbol{\%}$ & $\mathbf{l , ~} \mathbf{~ m m}$ & $\begin{array}{c}\mathbf{H V}, \mathbf{M P a} \\
\text { after deformation }\end{array}$ & $\begin{array}{c}\mathbf{H V}, \mathbf{M P a} \text { after annealing } \\
\mathbf{a t ~ 6 0 0} \mathbf{C o .}^{\circ} \mathbf{0 . 5} \mathbf{~ h}\end{array}$ \\
\hline 99.50 & 81.3 & 1.87 & 980 & 420 \\
\hline 99.90 & 81.3 & 1.87 & 980 & 370 \\
\hline 99.99 & 82.5 & 1.75 & 880 & 350 \\
\hline
\end{tabular}


The effect of platinum purity degree on the recrystallization temperature is shown in Figure I.3.
It is obvious that with increasing purity of platinum, the recrystallization temperature is reduced.

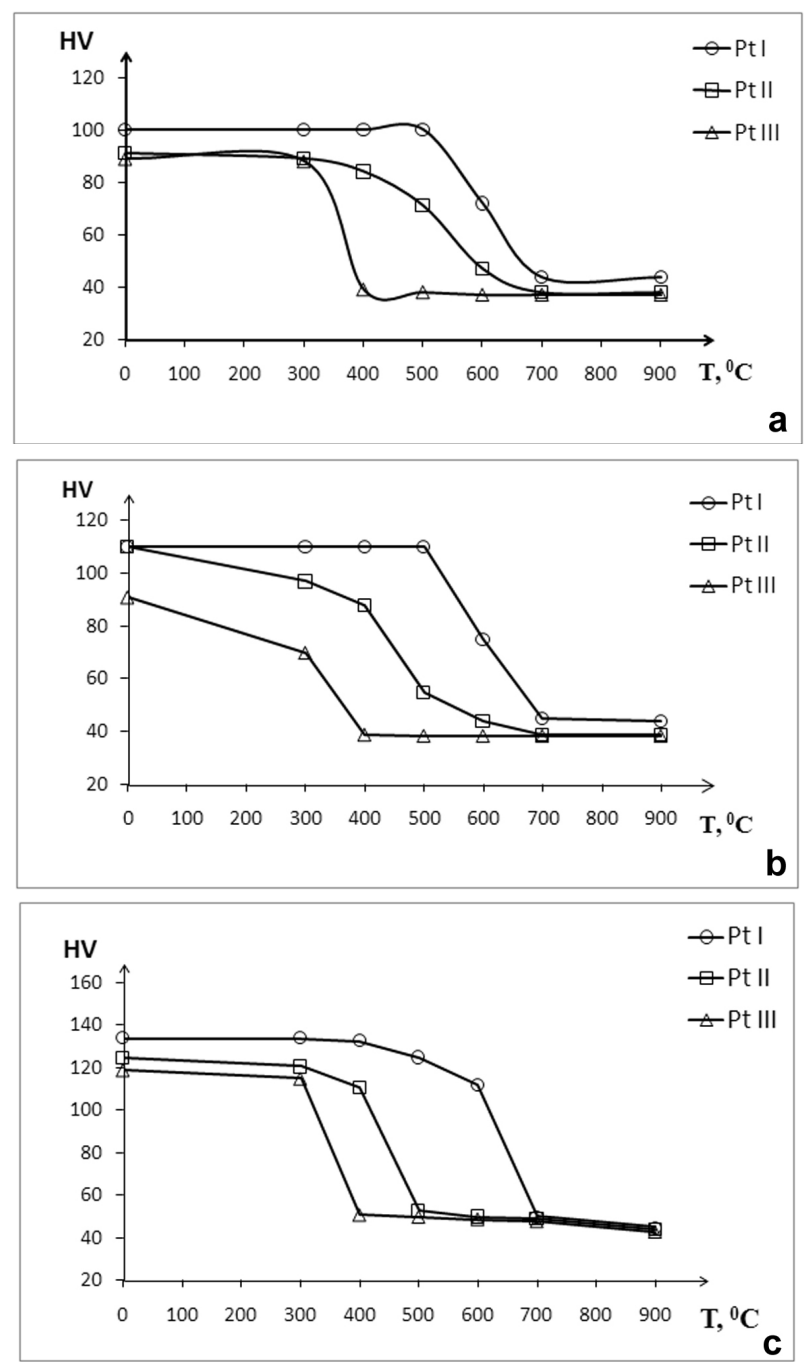

Figure 3 Dependence of platinum hardness of technical (PtI), chemical (PtII) and physical purity (PtIII) on temperature after annealing of 30 minutes at deformation degrees 82 (a), 90 (b) and 95\% (c)

Recrystallization of remelted technically pure platinum in an induction oven ends at $700^{\circ} \mathrm{C}$.

Testing the samples of platinum in the form of wire on break at $900^{\circ} \mathrm{C}$ has showed that with increasing purity, the time of re sistance and flow limit of platinum are reduced.

Testing results of samples after annealing at $900^{\circ} \mathrm{C}$ for a period of 1 hour were as follows: 


\begin{tabular}{|l|c|c|c|}
\hline Platinum purity & 99.50 & 99.90 & 99.99 \\
\hline $\mathbf{R}_{\mathbf{m}}, \mathbf{M P a}$ & 78 & 60 & 63 \\
\hline $\mathbf{R}_{\mathbf{p}} \mathbf{0 . 2}, \mathbf{M P a}$ & 46 & 31 & 30 \\
\hline $\mathbf{A}, \boldsymbol{\%}$ & 28 & 33 & 28 \\
\hline
\end{tabular}

Such lawfulness is only applied in the case of short-term tests in the specified temperature range. With increasing temperature and time of tests, the reciprocity of platinum and impurities are reinforced, and thus the effect on thermal resistance is changed.

\section{CONCLUSION}

Based on the previous research results, it can be said that some impurities are permissible in platinum, some must be strictly controlled in order to use the same for special purposes and in the end, the presence of certain impurities results in a disastrous outcome.

Therefore, platinum classification according to the purity and application in the exploitation conditions, based on extensive testing, can be conditionally as follows: for application at room temperature, maximum impurity content is $0.02 \%$. For operation at high temperatures the preferred platinum is with total impurity content below $0.013 \%$, while desirable platinum in the production of platinum thermocouples is with less than $0.002 \%$ of impurities. In the end, in making the equipment, in the glass industry, for a specific application in the production of optical glass fibers, platinum is recommended containing impurities of not more than $0.0010 \%$.

Total content of iron and copper in such platinum, must not be higher than $0.0001 \%$. In most cases, total content of these impurities does not exceed $0.0005 \%$.

In general, the conclusion is that if there is higher content of impurities in the platinum metals and alloys, the higher is proba bility of their negative impact on technological and exploitation properties.

\section{REFERENCES}

[1] H. Gavin, Platinum Group Metals Research from a Global Perspective, Platinum Met. Rev. 54 (2010) 166171;

[2] E. Preston, Platinum in the Glass Industry, Platinum Met. Rev. 4 (1960) 48-55;

[3] D.F. Lupton, J. Merker, B. Fischer, R. Völkl, Platinum Materials for the Glass Industry, 24 ${ }^{\text {th }}$ International Precious Metals Conference, Williamsburg, Virginia, USA, 1-14 June 2000;

[4] Y. Ning, Z. Yang, H. Zhao, Platinum Recovery by Palladium Alloy Catchment Gauzes in Nitric Acid Plants, Platinum Met. Rev.4 (1996) 80-87;

[5] N. Yuantao, Y. Zhengfen, Platinum Loss from Alloy Catalyst Gauzes in Nitric Acid Plants, Platinum Met. Rev. 43 (1999) 62-69;

[6] B. Trumić, D. Stanković, V. Trujić, Examining the Surfaces in Used Platinum Catalysts, Journal of Mining and Metallurgy 45 (1) B (2009) 79 - 87;

[7] B. Wu, G. Liu, Platinum: PlatinumRhodium Thermocouple Wire, Platinum Met. Rev. 41 (1997) 81-85;

[8] M. Funabikia, T. Yamadaa, K. Kayanoa, Auto Exhaust Catalysts, Catal. Today 10 (1991) 33-43;

[9] T. Biggs, S.S. Taylor, E. Van der Lingen, The Hardening of Platinum Alloys for Potential Jewellery Application, Platinum Met. Rev. 49 (2005) 2-15; 
[10] John C. Wright, Jewellery-Related Properties of Platinum: Low Thermal Diffusivity Permits Use of Laser Welding for Jewellery Manufacture, Platinum Metals Rev., 2002, 46 (2), 66-72;

[11] F. Xiao, F. Zhao, D. Mei, Z. Mo, B. Zeng, Nonenzymatic Glucose Sensor Based on Ultrasonic-Electrodeposition of Bimetallic PtM ( $\mathrm{M}=\mathrm{Ru}, \mathrm{Pd}$ and $\mathrm{Au}$ ) Nanoparticles on Carbon Nanotubes-Ionic Liquid Composite Film, Biosens. Bioelectron. 24 (2009) 34813486;

[12] I. R. McGill, Some Ternary and Higher Order Platinum Group Metal
Alloys, Platinum Metals Rev., 1987, 31, (2), 74-90;

[13] J. Luyten, J. De Keyzer, P. Wollants, C. Creemers, Construction of Modified Embedded Atom Method Potentials for the Study of the Bulk Phase Behaviour in Binary $\mathrm{Pt}-\mathrm{Rh}, \mathrm{Pt}-\mathrm{Pd}$, Pd-Rh and Ternary Pt-Pd-Rh Alloys, Calphad 33 (2009) 370-376;

[14] J. Luyten, C. Creemers, Surface Segregation in Ternary Pt-Pd-Rh Alloys Studied with Monte Carlo Simulations and the Modified Embedded Atom Method, Surface Science 602 (2008) 2491-2495. 


\begin{tabular}{ll}
\hline \hline INSTITUT ZA RUDARSTVO I METALURGIJU BOR & ISSN: 2334-8836 (Štampano izdanje) \\
UDK: 622 & ISSN: 2406-1395 (Online) \\
\hline \hline
\end{tabular}

\title{
UTICAJ SADRŽAJA NEČISTOĆA NA VISOKOTEMPERATURNU OTPORNOST PLATINE I NJENIH LEGURA**
}

\begin{abstract}
Izvod
U radu su predstavljeni rezultati ispitivanja uticaja kako pojedinih, tako i ukupnog sadržaja primesa u platini i njenim legurama različite čistoće. Predstavljena je relativna verovatnoća raspodele $\mathrm{Al}, \mathrm{Si}, \mathrm{Fe}, \mathrm{Mg}, \mathrm{Ni}, \mathrm{Pb}, \mathrm{Cu}$ i Ag, kao i njihov maksimalni sadržaj u legurama sastava PtRh7, PtRh10, PtRh5Pd15 i PtRh5Pd15Ru1.5. Takođe, dati su rezultati uticaja stepena čistoće platine na njenu visokotemperaturnu otpornost, nakon primenjenog termomehaničkog režima prerade. Zaključak je da, ukoliko je viši sadržaj nečistoća u platinskim metalima i legurama, utoliko je veća verovatnoća njihovog negativnog uticaja na tehnološka i eksploataciona svojstva.
\end{abstract}

Ključne reči: nečistoće, platina, platinske legure, visokotemperaturna otpornost

\section{UVOD}

Prisustvo hemijskih elemenata - nečistoća u platinskim metalima i legurama povezano je sa sastavom polaznih rudnih sirovina kao i sa tehnološkim operacijama njihovog dobijanja, prerade i eksploatacije $\mathrm{u}$ industrijskim uslovima [1-3].

Prisustvo nečistoća u platinskim metalima i legurama ima veliki uticaj na njihova fizička i mehanička svojstva. Iz tog razloga, čistoća platinskih metala i legura jedna je od njihovih ključnih karakteristika [4-6]. Za ocenu zbirnog sadržaja nečistoća često se koristi uslovna definicija platinskih metala tehničke $(99.50 \%$ tež.), hemijske $(99.90 \%$ tež.), fizičke ( $99.99 \%$ tež.) i spektralne (99.999\% tež.) čistoće. Saglasno sadašnjem standardu platinski metali podeljeni su u tri grupacije: tip A-0, A-1 i A-2 kojima odgovaraju sledeće čistoće: 99.98, 99.95 i 99.90\% [7-11].
Čistoća platine određuje se računskim putem iz razlike $100 \%$ mase metala i sume procenta 10-15 kontrolnih nečistoća. Pri tom, u ukupnom broju kontrolnih nečistoća, po pravilu nalaze se i metali platinske grupe i zlato. Nečistoće poput $\mathrm{Rh}, \mathrm{Ru} \mathrm{Pd}$, Ir i Au dovode do poboljšanja mehaničkih karakteristika platine, odnosno do porasta njene visoko temperaturne otpornosti [13].

$\mathrm{Na}$ primer, zaprljana platina sa sadržajem $0.055 \%$ drugih platinskih metala i zlata, može biti znatno bolji šaržni materijal u odnosu na čistu platinu tipa A-0 sa $0.01 \%$ nečistoća poput $\mathrm{Si}, \mathrm{Al}, \mathrm{Pb}$ i drugih, ali istovremeno predstavljati vrlo nepodoban šaržni materijal za izradu visokotemperaturnih legura. Međutim, bitna klasifikacija platinskih metala ne uzima u obzir mogućnost postojanja 50-70 obično ne kontrolnih nečistoća, čiji zbirni sadržaj može iznositi $10^{-2}-10^{-3} \%$ tež [14].

\footnotetext{
* Institut za rudarstvo i metalurgiju Bor, Zeleni bulevar 33, Bor, Srbija

** Ovaj rad je nastao kao rezultat projekta TR 34029,"Razvoj tehnologije proizvodnje Pd katalizatorahvatača za smanjenje gubitaka platine u visoko temperaturnim procesima katalize", finansiran od strane Ministarstva prosvete, nauke i tehnološkog razvoja Republike Srbije
} 


\section{EKSPERIMENTALNA TEHNIKA}

Platina, rodijum i paladijum za izradu legura su dobijeni kao sporedan proizvod $\mathrm{u}$ okviru proizvodnje elektrolitičkog bakra
RTB, Srbija. Dodatnom rafinacijom postignuta je neophodna čistoća. Sastav ispitivanih legura je naveden u tabeli 1 .

Tabela 1. Sadržaj legirnih elemenata u ispitivanim uzorcima (maseni \%)

\begin{tabular}{|l|c|c|c|}
\hline Legura & Rh (mas.\% ) & Pd (mas. \%) & Ru (mas. \%) \\
\hline PtRh7 & 7 & - & - \\
\hline PtRh10 & 10 & - & - \\
\hline PtRh5Pd15 & 5 & 15 & - \\
\hline PtRh5Pd15Ru1.5 & 5 & 15 & 1.5 \\
\hline
\end{tabular}

Topljenje uzoraka vršeno je u srednjefrekventnoj indukcionoj peći. Žarenje uzoraka vršeno je u elektrootpornoj peći tipa LP08.

Za ispitivanje mehaničkih karakteristika uzoraka na visokim temperaturama korišćen je univerzalni aparat za ispitivanje materijala zatezanjem na viskoim temperaturama, proizvođača Karl Frank, tip 81221.

Hemijska analiza materijala za uzorke izvršena je na atomskom apsorpcionom spektrofotometru.

\section{REZULTATI I DISKUSIJA}

Proizvodi na bazi platine i njenih legura nalaze veliku primenu u mnogim granama savremene industrije, pre svega $u$ hemijskoj industriji.

Za dugotrajnost i efikasnost navedenih proizvoda u eksploatacionim uslovima, veoma je bitna čistoća polaznih materijala.

U tom cilju, kontrola sadržaja nečistoća u platini i platinskim legurama, u svim fazama tehnološkog i eksploatacionog procesa, zauzima veoma bitno mesto.

Rezultati ispitivanja sadržaja pojedinih nečistoća u polaznom materijalu (Pt tipa A-1 (99.95\% tež.)), od kojih je sintetizovana legura sastava PtRh20Pd10Ir0.1Au0.1 dati su u tabeli 2 .

Tabela 2. Pojedinačni sadržaj nečistoća u platini čistoće $99.95 \%$

\begin{tabular}{|c|c|c|c|c|c|c|c|c|c|}
\hline Element & Be & B & F & Na & He & Ge & As & Se & Pr \\
\hline c $\times 10^{-5,}, \%$ & $0.03-0.09$ & $0.01-0.60$ & $7.0-80$ & $0.2-40$ & $1.3-8.3$ & $2.8-7.7$ & $1.5-22$ & $0.06-3.9$ & $1.5-2.7$ \\
\hline
\end{tabular}

\begin{tabular}{|c|c|c|c|c|c|c|c|c|c|}
\hline Element & $\mathbf{T i}$ & $\mathbf{V}$ & $\mathbf{C r}$ & $\mathbf{N d}$ & $\mathbf{S m}$ & $\mathbf{E u}$ & $\mathbf{M g}$ & $\mathbf{A l}$ & $\mathbf{S i}$ \\
\hline $\mathrm{c} \times 10^{-5}, \%$ & $1.8-230$ & $0.08-3.0$ & $2.5-13$ & $1.5-2.8$ & $1.5-2.9$ & $1.6-3.0$ & $3.0-90$ & $0.8-480$ & $1.7-82$ \\
\hline
\end{tabular}

\begin{tabular}{|c|c|c|c|c|c|c|c|c|c|}
\hline Element & $\mathbf{P}$ & $\mathbf{S}$ & $\mathbf{C l}$ & $\mathbf{K}$ & $\mathbf{C a}$ & $\mathbf{R b}$ & $\mathbf{S r}$ & $\mathbf{Y}$ & $\mathbf{Z r}$ \\
\hline $\mathrm{c} \mathrm{x} 10^{-5}, \%$ & $0.05-12$ & $0.8-2.8$ & $0.07-3100$ & $0.1-2.2$ & $0.5-31$ & $0.1-5.1$ & $0.1-0.3$ & $0.2-0.5$ & $0.4-3.3$ \\
\hline
\end{tabular}

\begin{tabular}{|c|c|c|c|c|c|c|c|c|c|}
\hline Element & Nb & Mo & Ag & Dy & Ho & Er & Tm & Yb & Lu \\
\hline c x $10^{-5}, \%$ & $0.1-0.6$ & $0.3-9.3$ & $2.0-62$ & $1.7-3.2$ & $1.7-3.2$ & $1.7-3.2$ & $1.7-3.3$ & $1.8-3.4$ & $1.8-3.4$ \\
\hline
\end{tabular}

\begin{tabular}{|c|c|c|c|c|c|c|c|c|c|}
\hline Element & Sc & Mn & Fe & Co & Ni & Cu & Zn & Br & Cd \\
\hline $\mathrm{c} \times 10^{-5}, \%$ & $0.04-0.46$ & $0.5-1.1$ & $0.05-370$ & $10 .-23$ & $3.9-520$ & $3.6-85$ & $1.7-310$ & $0.9-4.1$ & $1.6-3.1$ \\
\hline
\end{tabular}




\begin{tabular}{|c|c|c|c|c|c|c|c|c|c|}
\hline Element & $\mathbf{T b}$ & $\mathbf{O}_{\mathbf{2}}$ & $\mathbf{C}$ & $\mathbf{C u}$ & $\mathbf{I n}$ & $\mathbf{S n}$ & $\mathbf{S b}$ & $\mathbf{T e}$ & $\mathbf{I}$ \\
\hline $\mathrm{c} \times 10^{-5}, \%$ & $1.6-3.1$ & 310 & 15 & $0.9-6.5$ & $0.3-3.4$ & $2.3-11$ & $1.0-4.2$ & $6.2-36$ & $0.3-2.4$ \\
\hline
\end{tabular}

\begin{tabular}{|c|c|c|c|c|c|c|c|c|c|}
\hline Element & Cs & Ba & La & Ce & Hf & Ta & W & Re & Hg \\
\hline $\mathrm{c} \times 10^{-5}, \%$ & $4.1-18$ & $0.4-4.0$ & $1.4-2.7$ & $1.4-2.7$ & $1.2-3.5$ & $3.4-22$ & $2.8-8.9$ & $1.9-11$ & $1.6-9.0$ \\
\hline
\end{tabular}

\begin{tabular}{|c|c|c|c|c|c|}
\hline Element & Tl & Pb & Bi & Th & U \\
\hline $\mathrm{c} \times 10^{-5}, \%$ & $0.3-34$ & $5.9-110$ & $0.7-61$ & $0.8-1.6$ & $0.9-1.8$ \\
\hline
\end{tabular}

Očigledno je, da pojedinačni sadržaj neisparljivih nečistoća u platini tipa A-1 (99.95\%) i legurama na bazi njih kreće se u granicama od c x $10^{-7}$ do c $\times 10^{-3} \%$. Ukupni sadržaj svih 68 nečistoća neplemenitih metala i Ag ne prelazi $0.02 \%$.
U platinskim legurama namenjenim industrijskim uslovima ukupni sadržaj 1012 kontrolnih nečistoća, u mnogim slučajevima može biti veoma visok, do $0.1 \%$, premda često ne bude više od $0.02-0.05 \%$ (tabela 3 i slika 1).

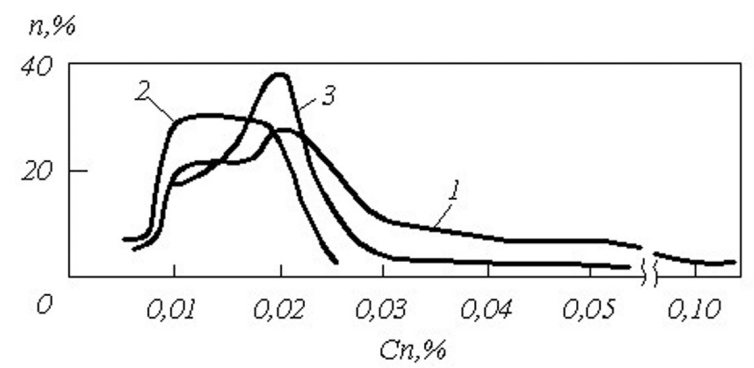

SI. 1. Relativna verovatnoća raspodele kontrolnih nečistoća (n), u funkciji koncentracije, $c_{n}$, u legurama PtRh10 (1), PtRh7 (2) i PtRh5Pd15 (3) [12 ]

Tabela 3. Maksimalni sadržaj kontrolnih nečistoća neplemenitih metala i Ag u platinskim legurama $\mathrm{u}$ tež \%

\begin{tabular}{|c|c|c|c|c|}
\hline Nečistoće & PtRh7 & PtRh10 & PtRh5Pd15 & PtRh10Pd25Ru1.5 \\
\hline $\mathbf{A g}$ & 0.003 & 0.012 & 0.003 & 0.003 \\
\hline $\mathbf{F e}$ & 0.010 & 0.030 & 0.015 & 0.010 \\
\hline $\mathbf{M g}$ & 0.020 & 0.025 & 0.020 & 0.010 \\
\hline $\mathbf{C u}$ & 0.001 & 0.001 & 0.014 & 0.003 \\
\hline $\mathbf{N i}$ & - & - & 0.003 & - \\
\hline $\mathbf{P b}$ & - & - & 0.003 & - \\
\hline $\mathbf{A l}$ & 0.005 & 0.006 & 0.002 & 0.003 \\
\hline $\mathbf{S i}$ & - & 0.007 & 0.003 & 0.002 \\
\hline $\mathbf{S}$ & - & 0.010 & - & - \\
\hline$\Sigma$ & 0.04 & 0.10 & 0.07 & 0.03 \\
\hline
\end{tabular}

Koncentracija pojedinih nečistoća uglavnom je niža od 0.001 do $0.002 \%$, a može biti slučajeva, kada sadržaj pojedinih nečistoća raste do $0.004-0.006 \%$ i dalje do $0.01-0.03 \%$, kako je predstavljeno na slici 2. 

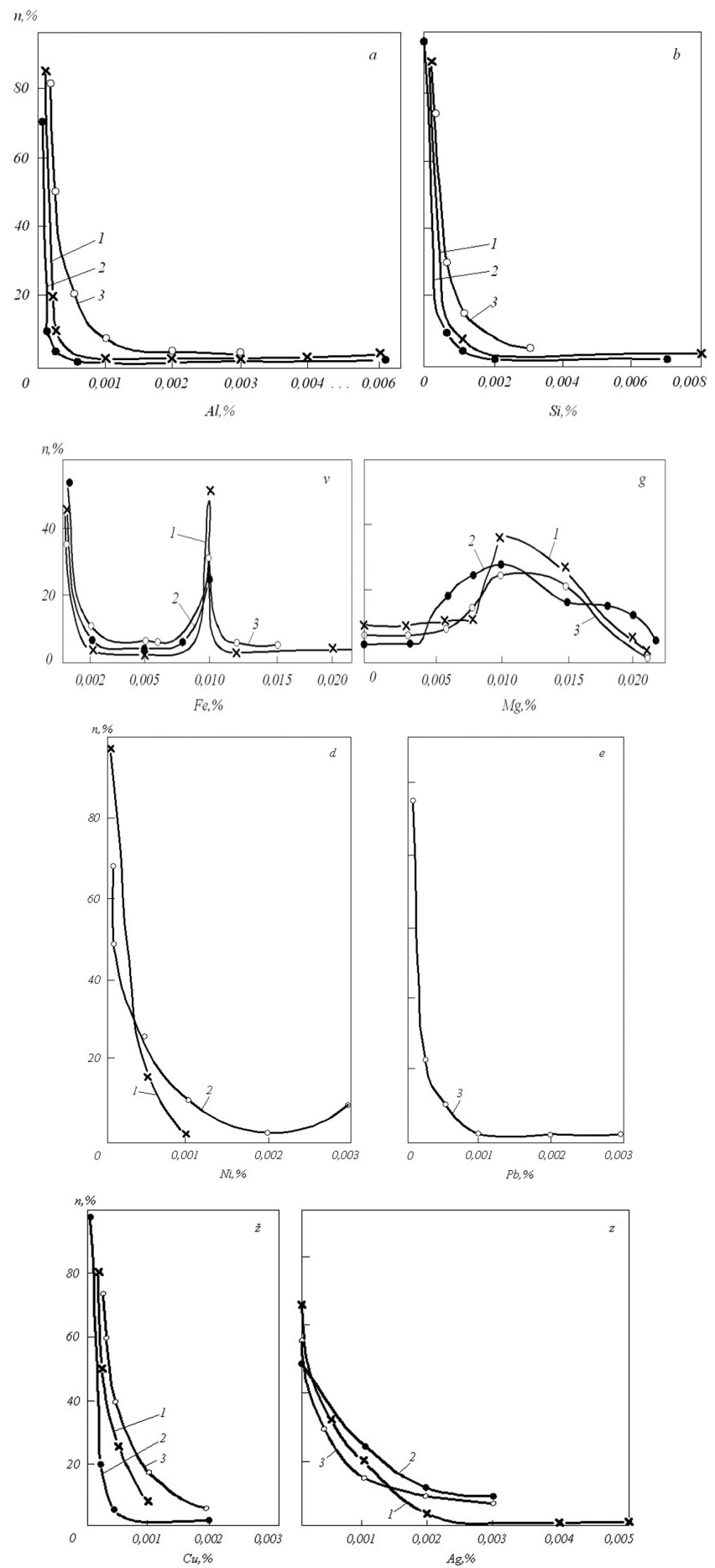

Sl. 2. Relativna verovatnoća raspodele aluminijuma (a), silicijuma (b), železa (v), magnezijuma (g), nikla (d), olova (e), bakra (ž) i srebra (z) u legurama PtRh10 (1), PtRh7 (2) i PtRh5Pd15Rul.5 
Posebnu pažnju skreće raspodela $\mathrm{Mg}$ i Fe (pri sadržaju višem od $0.005 \%$ ), koja se karakteriše celim Gausovim krivama, dok raspodela drugih analiziranih nečistoća predstavlja samo desnu stranu krive raspodele po Gausu. Pretpostavka je da se vrh i leva strana krive raspodele po Gausu, nalaze u oblasti tako niskih koncentracija za analizirane nečistoće, koje je nemoguće identifikovati korišćenjem metode spektralne analize.

Maksimum na krivima raspodele ukupnog sadržaja, slika 1 , kao i raspodele Fe i $\mathrm{Mg}$, slika 2, odgovaraju koncentraciji od $0.01-0.02 \%$. Očigledno je, da su Fe i $\mathrm{Mg}$ osnovni zagađivači platinskih legura. $\mathrm{Na}$ krivoj raspodele Fe karakteristična su dva maksimuma, pri koncentraciji od 0.001 i $0.01 \%$. Levi maksimum (koncentracija od $0.001 \%$ ) odgovara sadržaju železa u polaznoj šarži, dok desni maksimum (koncentracije $0.01 \%$ ) najverovatnije odgovara zaprljanju legure u pocesu prerade i eksploatacije.

Zaprljanje platinskih legura magnezijumom u količini od $0.005-0.015 \%$ pove- zano je sa topljenjem platinskih legura $u$ keramičkim loncima sastava $\mathrm{MgO}$, s obzirom da sadržaj magnezijuma u polaznoj šarži ne prelazi koncentraciju od 0.001 0.003 .

Prema Engleskom standardu, za platinu visoke čistoće dozvoljen je sadržaj sledećih nečistoća u \%:

$1 \times 10^{-5} \mathrm{Cu} ; 1 \times 10^{-5} \mathrm{Ag} ;<1 \times 10^{-4} \mathrm{~Pb}$;

$7 \times 10^{-5} \mathrm{Fe} ;<1 \times 10^{-4} \mathrm{Ni} ;<1 \times 10^{-4} \mathrm{Mg}$;

$<1 \times 10^{-5} \mathrm{Zr} ; 4 \times 10^{-4} \mathrm{O}_{2} ; 2 \times 10^{-5} \mathrm{Pd}$;

$2 \times 10^{-5} \mathrm{Rh} ;<1 \times 10^{-4} \mathrm{Au}[12]$.

$\mathrm{Na}$ osnovu dozvoljenih sadržaja nečistoća, prema navedenom standardu, do platine visoke čistoće može se doći jedino pri njenom dobijanju hemijskim putem, dok se zonalnom rafinacijom u struji kiseonika ili uklanjanjem nečistoća na visokim temperaturama u struji kiseonika ili vakuuma, mogu znatno smanjiti količine navedenih nečistoća.

U tabeli 4 predstavljeni su rezultati dobijeni tehnikom AAS za platinu čistoće 99,999\%.

Tabela 4. Sadržaj nečistoća u platini čistoće $99.999 \%$

\begin{tabular}{|c|c|c|c|c|c|c|c|c|c|}
\hline Element & Pb & W & Ta & Ag & Cu & Ni & Fe & Cr & Ti \\
\hline c $\times 10^{-4}, \%$ & $1 \times 10^{-5}$ & $4 \times 10^{-6}$ & $3 \times 10^{-5}$ & $6 \times 10^{-6}$ & $5 \times 10^{-6}$ & $1.5 \times 10^{-4}$ & $2 \times 10^{-3}$ & $1.2 \times 10^{-4}$ & $1.4 \times 10^{-4}$ \\
\hline
\end{tabular}

\begin{tabular}{|c|c|c|c|c|c|c|c|c|c|}
\hline Element & $\mathbf{C a}$ & $\mathbf{S}$ & $\mathbf{P}$ & $\mathbf{S i}$ & $\mathbf{A l}$ & $\mathbf{M g}$ & $\mathbf{N a}$ & $\mathbf{O}_{\mathbf{2}}$ & $\mathbf{N}$ \\
\hline $\mathrm{c} \times 10^{-5}, \%$ & $3 \times 10^{-4}$ & $3 \times 10^{-4}$ & $1 \times 10^{-4}$ & $7 \times 10^{-4}$ & $1 \times 10^{-3}$ & $3 \times 10^{-4}$ & $1 \times 10^{-4}$ & $3 \times 10^{-3}$ & $1 \times 10^{-3}$ \\
\hline
\end{tabular}

\begin{tabular}{|c|c|c|c|c|}
\hline Element & B & Au & Pd & Rh \\
\hline $\mathrm{c} \times 10^{-5}, \%$ & $4 \times 10^{-3}$ & $3 \times 10^{-5}$ & $2.7 \times 10^{-3}$ & $3 \times 10^{-5}$ \\
\hline
\end{tabular}

Težnja ka dobijanju platinskih metala i legura visoke čistoće usmerena su ka cilju postizanja određenih eksploatacionih karakteristika, kao i neophodnosti sprečavanja obrazovanja naprslina pri toplom kovanju i preradi metala.

U Tabeli 5 dati su rezultati uticaja stepena čistoće na tvrdoću platine nakon deformacije i žarenja na $600^{\circ} \mathrm{C}$ u trajanju od $0.5 \mathrm{~h}$.

Tabela 5. Tvrdoća platine različite čistoće (lim)

\begin{tabular}{|c|c|c|c|c|}
\hline Čistoća platine & $\varepsilon, \%$ & $\mathbf{l}, \mathbf{m m}$ & $\begin{array}{c}\text { HV, Mpa nakon } \\
\text { deformacije }\end{array}$ & $\begin{array}{l}\text { HV, Mpa nakon žarenja } \\
\text { na } 600{ }^{\circ} \mathrm{C}, 0.5 \mathrm{~h}\end{array}$ \\
\hline 99.50 & 81.3 & 1.87 & 980 & 420 \\
\hline 99.90 & 81.3 & 1.87 & 980 & 370 \\
\hline 99.99 & 82.5 & 1.75 & 880 & 350 \\
\hline
\end{tabular}


Uticaj stepena čistoće platine na temperaturu rekristalizacije prikazan je na slici 3 .
Očigledno je da se sa povećanjem čistoće platine smanjuje temperatura rekristalizacije.

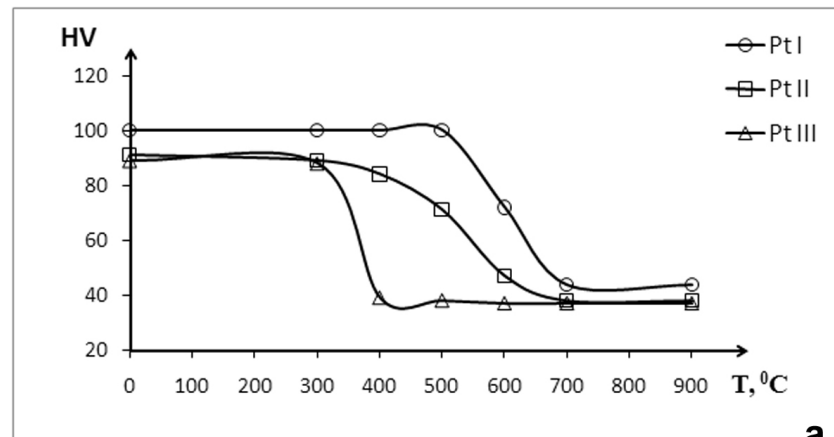

a
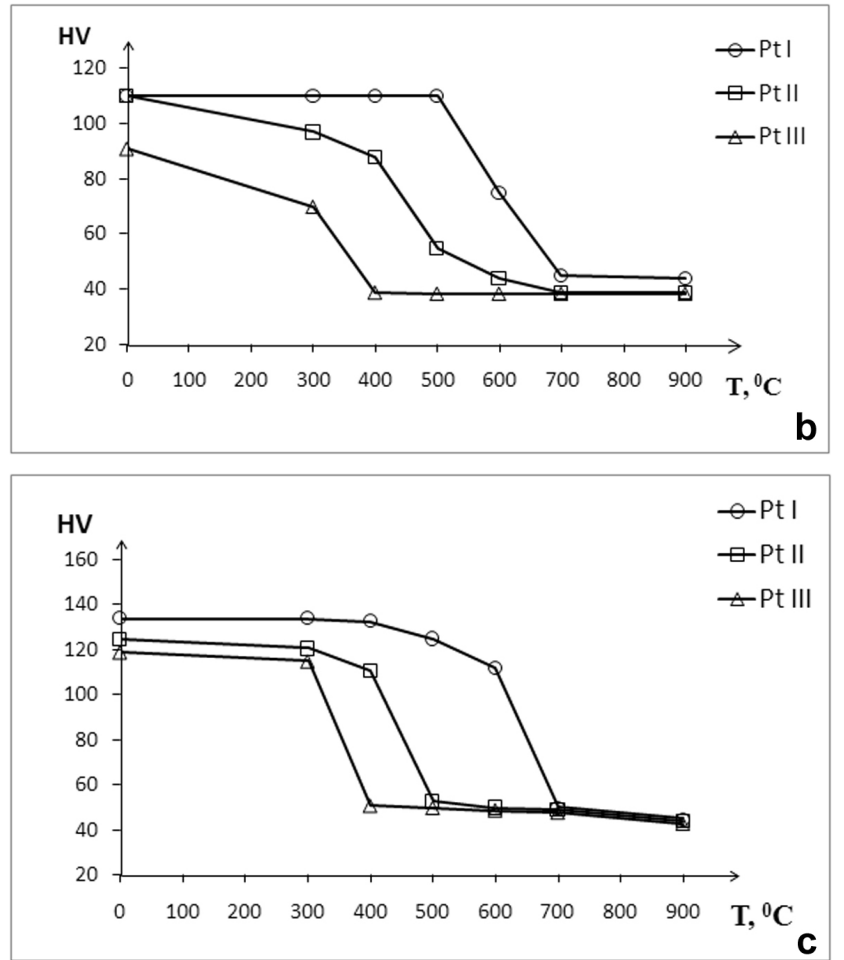

Sl. 3. Zavisnost tvrdoće platine tehničke (PtI), hemijske (PtII) I fizičke čistoće (PtIII), od temperature nakon 30 minutnog žarenja, pri stepenima deformacije 82 (a), 90 (b) $i$ 95\% (c)

Rekristalizacija pretopljene tehnički čiste platine $\mathrm{u}$ indukcionoj peći završava se na $700^{\circ} \mathrm{C}$.

Ispitivanjem uzoraka platine u obliku žice na prekid, na $900^{\circ} \mathrm{C}$, pokazalo je, da se sa povećanjem čistoće, vreme otpora i granica tečenja platine se smanjuju.

Rezultati ispitivanja uzoraka nakon žarenja na $900^{\circ} \mathrm{C}$, u trajanju od $1 \mathrm{~h}$ su sledeći: 


\begin{tabular}{|l|c|c|c|}
\hline Čistoća platine & 99.50 & 99.90 & 99.99 \\
\hline $\mathbf{R}_{\mathbf{m}}, \mathbf{M P a}$ & 78 & 60 & 63 \\
\hline $\mathbf{R}_{\mathbf{p}} \mathbf{0 . 2}, \mathbf{M P a}$ & 46 & 31 & 30 \\
\hline $\mathbf{A}, \boldsymbol{\%}$ & 28 & 33 & 28 \\
\hline
\end{tabular}

Ovakva zakonitost važi samo u slučaju kratkovremenih ispitivanja u navedenom temperaturnom intervalu. Sa povećanjem temperature i vremena ispitivanja pojačava se uzajamno dejstvo platine i nečistoća, pa samim tim uticaj na temperaturnu otpornost se menja.

\section{ZAKLJUČAK}

$\mathrm{Na}$ osnovu dosadašnjih rezultata istraživanja, može se reći da, u platini neke nečistoće su dopustive, neke se moraju strogo kontrolisati radi korišćenja iste $\mathrm{u}$ specijalne svrhe i na kraju, prisustvo određenih nečistoća ima za posledicu katastrofalan ishod.

Zato, klasifikacija platine prema čistoći i primeni u eksploatacionim uslovima, na osnovu obimnih ispitivanja, uslovno može biti sledeća: za primenu na sobnoj temperaturi maksimalni sadržaj nečistoća iznosi $0.02 \%$. Za rad na visokim temperaturama najpoželjnija je platina sa ukupnim sadržajem nečistoća ispod $0.013 \%$, dok je za izradu termoparova poželjna platina sa manje od $0.002 \%$ nečistoća. Na kraju, za izradu opreme, u industriji stakla, za konkretnu primenu kod proizvodnje optičkih staklenih vlakana, preporučuje se platina sa sadržajem nečistoća ne većim od $0.0010 \%$.

Ukupan sadržaj železa i bakra u takvoj platini, ne sme biti veći od $0.0001 \%$. U većini slučajeva, ukupan sadržaj ovih nečistoća ne prelazi $0.0005 \%$.

Generalno, zaključak je, da ukoliko je viši sadržaj nečistoća u platinskim metalima i legurama, utoliko je veća verovatnoća njihovog negativnog uticaja na tehnološka i eksploataciona svojstva.

\section{LITERATURA}

[1] H. Gavin, Platinum group metals research froma global perspective, Platinum Met. Rev. 54 (2010) 166-171.

[2] E. Preston, Platinum in the glass industry, Platinum Met. Rev.4 (1960) 4855.

[3] D. F. Lupton, J. Merker, B. Fischer, R. Völkl, Platinum Materials for the glass industry, $24^{\text {th }}$ International Precious Metals Conference, Williamsburg, Virginia, USA, 1-14 June 2000.

[4] Y. Ning, Z. Yang, H. Zhao, Platinum recovery by palladium alloy catchment gauzes in nitric acid plants, Platinum Met. Rev. 4 (1996) 80-87.

[5] N. Yuantao, Y. Zhengfen, Platinum loss from alloy catalyst gauzes in nitric acid plants, Platinum Met. Rev. 43 (1999) 62-69.

[6] B. Trumić, D. Stanković, V. Trujić, Examining the surfaces in used platinum catalysts, Journal of Mining and Metallurgy 45 (1) B (2009) 79 - 87.

[7] B. Wu, G. Liu, Platinum: Platinumrhodium thermocouple Wire, Platinum Met. Rev. 41 (1997) 81-85.

[8] M. Funabikia, T. Yamadaa, K. Kayanoa, Auto exhaust catalysts, Catal. Today 10 (1991) 33-43.

[9] T. Biggs, S.S. Taylor, E. Van der Lingen, The hardening of platinum alloys for potential jewellery application, Platinum Met. Rev. 49 (2005) 2-15. 
[10] John C. Wright, Jewellery-Related Properties of Platinum: Low Thermal Diffusivity Permits Use of Laser Welding for Jewellery Manufacture, Platinum Metals Rev., 2002, 46 (2) 66-72.

[11] F. Xiao, F. Zhao, D. Mei, Z. Mo, B. Zeng, Nonenzymatic glucose sensor based on ultrasonic-electrodeposition of bimetallic PtM ( $\mathrm{M}=\mathrm{Ru}, \mathrm{Pd}$ and $\mathrm{Au})$ nanoparticles on carbon nanotubes-ionic liquid composite film, Biosens. Bioelectron. 24 (2009) 34813486.

[12] I. R. McGill, Some Ternary and Higher Order Platinum Group Metal
Alloys, Platinum Metals Rev., 1987, 31, (2), 74-90.

[13] J. Luyten, J. De Keyzer, P. Wollants, C. Creemers, Construction of modified embedded atom method potentials for the study of the bulk phase behaviour in binary $\mathrm{Pt}-\mathrm{Rh}, \mathrm{Pt}-\mathrm{Pd}, \mathrm{Pd}-\mathrm{Rh}$ and ternary Pt-Pd-Rh alloys, Calphad 33 (2009) 370-376.

[14] J. Luyten, C. Creemers, Surface segregation in ternary $\mathrm{Pt}-\mathrm{Pd}-\mathrm{Rh}$ alloys studied with Monte Carlo simulations and the modified embedded atom method, Surface Science 602 (2008) 2491-2495. 